\title{
Peningkatan Kreativitas Melalui Pelatihan Finger Painting Bagi Guru PAUD
}

\author{
Rista Sundari \\ PIAUD, Fakultas Ilmu Tarbiyah dan Keguruan, UIN Walisongo Semarang \\ rista.sundari33@gmail.com \\ Fatimatul Zahroh \\ PIAUD, Fakultas Ilmu Tarbiyah dan Keguruan, UIN Walisongo Semarang \\ fatimatuzzahrah65@gmail.com
}

\begin{abstract}
Creativity is a very important aspect for everyone because with creativity everyone can express ideas and solve problems creatively. The purpose of the preparation of this research is for PAUD teachers to be able to increase creativity in early childhood learning, especially through finger painting practice training. The research method used is a library research method with data collection techniques from several sources and relevant literature accompanied by content analysis. Teachers are required not only to produce good learning in transforming science but also to hone the potential that exists in students. The results showed that with the training, there were many benefits or advantages obtained by teachers as educators to be able to carry out the teaching and learning process creatively, innovatively, and potentially.
\end{abstract}

Keywords : Training; Creativity; Finger Painting; Early Childhood,; Teachers 


\section{ABSTRAK}

Kreativitas merupakan aspek yang sangat penting bagi setiap orang, karena dengan kreativitas setiap orang mampu menuangkan ide-ide dan menyelesaikan permasalahan secara kreatif. Tujuan dari penyusunan penelitian ini agar guru PAUD mampu meningkatkan kreativitas dalam pembelajaran anak usia dini khususnya dengan pelatihan praktik finger painting. Metode penelitian yang digunakan merupakan metode penelitian kepustakaan dengan teknik pengumpulan data dari beberapa sumber dan literatur yang relevan disertai dengan analisis isi. Guru dituntut tidak hanya menghasilkaan pembelajaran yang baik dalam transforming science, tetapi juga harus mengasah potensi yang ada pada diri peserta didik. Hasil penelitian menunjukan bahwa dengan adanya pelatihan, banyak manfaat atau kelebihan yang didapatkan guru sebagai tenaga pendidik untuk dapat menjalankan proses belajar mengajar secara kreatif, inovatif serta potensial.

Kata kunci : Pelatihan; Kreativitas; Finger Painting,; Guru; PAUD; 
75 Rista Sundari and Fatimatul Zahroh

\section{PENDAHULUAN}

Permasalahan yang mendasar pada bidang pendidikan berupa kurangnya perbaikan kualitas terutama sumber daya manusia khususnya pada para pendidik yang tidak optimal dalam mengembangkan potensinya. Keberhasilan menyelenggarakan pendidikan dapat dilihat sejauh mana pendidik memberikan perannya karena untuk mencapai proses pembelajaran itu berhasil atau tidaknya ditentukan oleh guru yang dapat menjalankan proses belajar mengajar secara kreatif, inovatif dan potensial. Guru merupakan gambaran yang akan tampak dan terpengaruh untuk lingkungan sekitar. Guru adalah pekerjaan yang mulia, guru adalah profesi yang menantang. Guru harus bisa memfasilitasi siswanya secara akademis dan perkembangan kepribadiannya. Seorang guru harus mengedepankan pengabdiannya secara totalitas. Guru yang baik adalah guru yang bisa menikmati pekerjaannya, yang bekerja keras, yang peduli kepada anak didiknya dan mampu mengaktifkan anak didiknya pada pembelajaran.

Guru Pendidikan Usia dini memegang peranan yang sangat penting khususnya bagi pertumbuhan mental serta emosional anak. Guru harus dapat memberikan rangsangan untuk perkembangan anak agar memiliki perkembangan yang optimal (Dewi Fitriani dkk, 2019). Menjadi guru yang kreatif dan inovatif bukan suatu hal yang mudah, tentu memerlukan proses yang panjang. Maka dari itu, untuk menjadi guru yang kreatif, inovatif dan berpotensi harus bisa menjaga komitmen untuk terus memberi spirit kreatif dan insipiratif kepada peserta didik. Pengembangan kreativitas serta kecerdasan emosional pada peserta didik salah satunya dapat dilaksanakan dengan metode bermain, dengan metode bermain anak merasakan tanpa adanya paksaan (Putri Rahmi, 2019). Spirit yang diberikan, guru dapat menciptakan manusia yang unggul dan penuh kreativitas serta memiliki kemampuan kompetitif. Guru yang menjadi insiprasi peserta didik adalah guru yang sebenarnya. Sebelum melimpahkan keinginannya kepada peserta didik maka seorang guru harus lebih dulu mempunyai kemampuan yang kreatif, produktif, kompetitif, serta inovatif. Jika diajar oleh guru yang inspiratif peserta didik akan mampu menerjemah apa yang dialami sekalipun meski tidak berkaitan dengan kurikulum yang ada. Guru yang inspiratif bukanlah seorang guru yang hanya mampu mengajar kurikulum, tapi dia yang bisa mengaja peserta didik untuk mampu berfikir secara kreatif. 


\section{METODOLOGI}

Penelitian ini menggunakan metode penelitian kepustakaan atau library research. Metode ini dipilih dan disusun agar menambah pengetahuan bagi guru terkait dengan pelatihan pembelajaran anak usia dini terutama pada kondisi pandemi. Penelitian ini dikhususkan pada praktik pelaksanaan pelatihan seni rupa finger painting untuk menambah pengetahuan dan wawasan guru AUD. Penelitian ini diharapkan dapat memicu kreativitas dan imajinasi guru anak usia dini agar tetap dapat mempraktikkan teknik finger painting. Langkahlangkah yang dilakukan pada penelitian ini adalah menentukan ide atau gagasan awal pelatihan finger painting yang dibutuhkan oleh guru anak usia dini, mempertimbangkan manfaat finger painting yang akan diperoleh, mencari referensi yang sesuai dengan materi yang dibutuhkan melalui buku, jurnal dan referensi lainnya yang relevan, menulis dengan fokus inti penelitian yang ditentukan yaitu khusus mengenaifinger painting dan diharapkan mendapatkan hasil penelitian dengan pengolahan dan pengorganisasian data dengan teori, metode serta analisis data. Teknik analisis data merupakan analisis isi untuk melihat kesesuaian dari topik yang sudah ditentukan sehingga didapatkan sebuah kesimpulan yang menjawab rumusan masalah.

\section{HASIL DAN PEMBAHASAN}

\section{Kreativitas dalam Pendidikan}

Guru merupakanprofesi yang dituntut untuk memiliki suatu keterampilan, mengembangkan pengetahuan, kreatif dalam menyampikan materi. Tujuan peningkatan kemampuam kreativitas guru selain untuk menunjang mutu pendidikan tujuannya adalah agar guru bisa menghadapi tantangan pada kondisi apapun, karena pada era ini merupakan era globalisasi yang penuh dengan persaingan. Guru yang memiliki kreativitas yang baik harus profesional dalam belajar mengajar. Adapun ciri-ciri guru yang kreatif adalah memiliki hasrat keinginan dan semangat yang kuat, bersikap terbuka terhadap pengalaman baru, memiliki gagasan dan pemecahan masalah serta usulan terhadap suatu masalah, memiliki dan mengapresiasi rasa keindahan, memiliki imajinasi yang kuat, memiliki pendapat yang tepat, mampu menyampaikannya sesuai dengan tema dan konteks pembahasan materi maupun praktik serta senang bereksperimen dalam berkreasi dan menemukan hal yang baru. 
Oleh sebab itu, guru harus menyadari betul fungsi dan perannya yaitu sebagai fasilitator pendidikan. Guru diharapkan selalu mengembangkan potensinya sehingga memiliki kreativitas yang tinggisaat melaksanakan kegiatan belajar mengajar sebagai transforming science. Kreativitas yang dimaksud disini adalah kreativitas yang tidak terbatas pada segelintir manusia tertentu. Toleransi dan selalu dinamis dengan keadaan menjadi kunci dalam menciptakan kreativitas(Jufni, 2015). Salah satu cara untuk meningkatkan kreativitas seorang guru adalah dengan memberikan pelatihan secara berkala, seperti pada peribahasa "pisau diasah semakin tajam" yang memiliki arti bahwa pisau diasah agar semakin tajam dan berfungsi dengan maksimal, sama halnya dengan manusia terutama seorang guru, jika seorang guru ingin menjadi guru yang penuh potensi dan siap dibutuhkan kapan pun hendaknya harus mengikuti pelatihan yang bisa menunjang kemampuannya.

Pelatihan dan pengembangan diri harus diikuti oleh seorang guru agar kemampuannya semakin meningkat. Mengikuti pelatihan mengembangkan diri merupakan proses untuk meningkatkan keterampilan baik dari segi teknis, teoritis, dan konseptual. Pemberian pelatihan terhadap guru harus dilakukan secara bertahap dan berkelanjutan. Pemberian pelatihan terhadap guru bertujuan agar guru mampu meningkatkan kemampuannya secara terprogam dan sistematik. Guru dapat membandingkan kemampuan yang dimiliki diri sendiri dengan orang lain maupun kondisi sekolah sehingga diharapkan mampu mengambangan kemampuan dan mengembangkan sekolah yang ditempati guru tersebut. Selain pelatihan ini memberikan tunjangan untuk menjadi guru yang berpotensi, pelatihan ini juga berdampak untuk menyalurkan kreativitas guru untuk peserta didik (Ismiyanto, 2018). Guru juga memiliki peranan penting untuk mengembangkan kreativitas yang dimiliki. Harus bisa menyalurkan potensi yang ada pada dirinya untuk peserta didik. Ada beberapa peran guru untuk meningkatkan kreativitas anak yaitu :

a. Menyukai tantangan dan kreatif. Guru hendaknya menyukai tantangan dan hal-hal baru, serta harus bersifat kreatif sehingga dia bisa mengembangkan, memperluas, memperdalam, memperbaharui aktifitas belajar mengajarnya dari waktu ke waktu.

b. Dapat menghargai karya anak. Kita harus bisa menghargai karyakarya anak agar anak bisa mengekspresikan dirinya secara bebas, 
dengan kita memberi pujian dan penghargaan anak bisa lebih termotivasi untuk menghasilkan karya yang lebih baik lagi.

c. Guru sebagai "Motivator". Guru harus dapat memberikan motivasi, respon positif. Ciptakan suasana kelas yang menyenangkan agar siswa tidak merasa jenuh.

d. Memiliki rasa cinta terhadap seni dan keindahan. Guru juga dapat berperan sebagai penyalur kreativitas untuk peserta didik seorang guru harus memiliki konsep dasar tentang estetika.

e. Mampu mengembangkan potensi peserta didik Setelah guru mengetahui potensi anak, selanjutnya tindakan seorang guru adalah mengembangkan potensi yang dimiliki peserta didik, agar potensi yang dimiliki berkembang secara baik dan optimal

f. Memiliki sikap Dinamis dan konsisten. Dinamis artinya mengalami perkembangan yang berarti, sikap dinamis ini harus dibarengi dengan sikap konsisten dari individu yang memiliki potensi tersebut. Konsisten berarti guru tidak mengeksploitasi yang bukan dari kemampuan anak.

g. Penuh penghayatan, ekspresif serta peka terhadap perasaan. Kematangan emosional seorang guru sangatlah penting, hal ini dilakukan agar seorang guru bisa mengamati hal-hal penting yang menyangkut hasil kreativitas anak.

h. Mau dan punya keinginan bermain dan berbagi. Bermain dalam dunia anak merupakan kegiatan belajar dan bekerja yang kreatif. Dalam hal ini guru harus bisa dan terlibat aktif membentuk dan merancang permainan yang diolah guna mengembangkan kreativitas anak.

i. Hangat dan penuh kasih sayang. Sentuhan kehangatan dari seorang guru akan menciptakan keadaan atau atmosfer yang baik untuk anak. Anak merasakankenyamanan tanpa merasakan ketakutan, jadi untuk mengembangkan kreativitasnya anak akan merasa bebas dan ekspresif.

j. Peduli pada perkembangan anak. Seorang guru diharapkan mampu mengetahui perkembangan anak, hal ini berfungsi untuk mengetahui perkembangannya agar bisa dinilai kreativitas anak yang sesuai dengan potensi yang dimiliki anak.

k. Tanggap, humble dan teliti. Mempunyai kepribadian yang baik akan sangat berpengaruh dalm pembentukan kreativitas anak. Sebisa mungkin guru harus mempunyai sikap hamble dan tanggap agar 
79| Rista Sundari and Fatimatul Zahroh

anak merasa diterima dan diperlakukan dengan baik dan senang saat mengembangkan kreativitasnya.

l. Guru sebagai pendorong aktivitas. Guru berperan penting untuk mendorong dan meningkatkan kreativitas peserta didiknya. Bisa mengoptimalkan perkembangan bakat dirinya agar bisa menyalurkan kepada peserta didiknya.

$\mathrm{m}$. Guru sebagai pembangkit pandangan. Merubah pandangan peserta didik yang semula tidak mau menyalurkan kreativitasnya menjadi semangat untuk meningkatkan kreativitasnya.

n. Guru sebagai emansipator. Guru harus cerdas dalam memahami peserta didiknya, menghormati, dan memberikan kebebasan bertanya sehingga bisa mengeskplorasi muridnya.

o. Guru sebagai pengembang. Guru mampu mengembangkan ilmu pengetahuan yang telah dituangkan kepada peserta didik dari waktu ke waktu. Dari generasi satu ke generasi berikutnya.

p. Guru sebagai evaluator. Hendaknya guru melaksanakan evaluasi secara terus menerus terhadap hasil belajar yang dilakuakan agar perkembangan peserta didik semakin baik.

Keterkatian antara kegiatan belajar peserta didik dengan kegiatan mengajar guru akan menghasilakan keterpaduan yang baik yang akan menimbulakan interaksi pembelajaran yang menyenangkan dan tidak membosankan. Jiwa kreativitas pada seoranag guru sangat berperan penting, karena setelah guru menyalurkan potensi yang dimiliki peserta didik juga bisa mengembangkan potensi yang mereka miliki karena guru merupakan sumber untuk menentukan keberhasilan sebuah pendidikan. Peserta didik harus diberikan dorongan dengan stimulasi kegiatan yang positif salah satunya dengan kegiatan mewarnai, kegiatan mewarnai ini dapat dilakukan dengan beberapa praktik yang mendukung (Pratiwi, P. Y., \& Budisetyani, I. W. ,2013). Kemampuan kreativitas seseorang itu berbeda, orang yang kreatif cenderung murni pada gagasan atau idenya. Orang kreatif akan lebih luwes mereka akan beralih kependekatan satu kependekatan yang lain apabila dihadapkan pada berbagai persoalan. Mereka senang pada hal-hal rumit yang membutuhkan ide kreatifitas sebagai solusinya serta memiliki kepribadian yang mandiri. Setiap orang pasti memiliki kreativitas, yang menjadi pembeda adalah bagaimana cara untuk mengembangkan potensinya. Pada dasarnya yang membedakan tingkat kreativitas seseorang itu terletak pada teknik yang berbeda. Seorang yang genius belum tentu memiliki kreatifitas yang tinggi. 
Mengembangkan kreativitas dapat dilakukan dengan intensif dalam berimajinasi, yaitu membebaskan pikiran secara leluasa sehingga ideide yang akan dituangkan akan lebih efektif. Mencari wawasan yang lebih dalam lagi agar bakat yang akan dikembangkan tidak itu-itu saja. Selalu berlatih dan mengembangkan potensi yang ada.

Meningkatkan kreativitas seorang pendidik, tentunya tidak bergantung pada potensi bawaan yang khusus saja tetapi harus ada mekanisme mental untuk meningkatkan pembawaan yang ada. Adapun faktor-faktor pendukung untuk meningkatkan kreativitas seorang guru adalah :

a. Mempunyai waktu yang longgar. Menjadi guru yang aktif dan kreatif membutuhkan waktu yang banyak gunanya untuk mencari gagasangagasan ide, konsep-konsep, teori-teori dalam proses pembelajarannya.

b. Adanya dukungan dan dorongan. Guru yang kreatif dan inovatis harus mempunyai dukungan dan dorongan tertentu, entah itu dorongan dari diri sendiri ataupun dari lingkungan sekitarnya.

c. Adanya fasilitas yang memadai. Guru yang penuh kreatif akan lebih kreatif dan bisa memproges kreativitasnya jika ditunjang oleh fasilitas yang lebih baik dan memadai.

d. Memiliki kesempatan untuk memperoleh pengetahuan. Potensi dan kreativitas tidak datang dengan sendirinya, tetapi didukung oleh pengetahuan yang dimiliki oleh guru karena semakin banyak pengetahuan yang dimiliki akan semakin baik pula kreativitas yang dimiliki.

e. Keaktifan guru dalam mengikuti kegiatan. Guru hendaknya mengikuti kegiatan yang banyak menunjang kreativitas atau kemampuannya agar selalu diasah dan bisa disalurkan dengan baik.

Adapun faktor penghambat kreativitas guru yaitu :

1) Kurangnya dorongan dari diri sendiri dan lingkungan

2) Kekakuan dalam berfikir

3) Tidak percaya diri

4) Tidak adanya sarana dan fasilitas yang dapat mendukung pengembangan kreativitas

5) Kurang berlatih dalam mengembangkan potensi yang ada pada dirinya(Adirestury, 2017). 


\section{FINGER PAINTING}

Finger painting merupakan kegiatan menggoreskan adonan warna secara langsung menggunakan jari serta telapak sampai pergelangan tangan untuk menghasilkan sebuah karya atau gambar. Kegiatan pelatihan finger painting ini dilakukan dengan cara memberikan pelatihan kepada guru PAUD supaya lebih kreatif dan inovatif agar saat menyalurkan potensi anak didik, peserta didik bisa lebih baik perkembangannya. Pelatihan ini harus dimulai dengan persiapan sampai kegiatan pelatihan. Pelatihan ini tidak difokuskan untuk guru PAUD yang sudah bersarjana melainkan guru PAUD yang bukan bersarjana diharapkan mereka juga bisa mengembangkan kreativitasnya agar lebih baik. Sebelum dimulainya pelatihan dilakukan kegiatan berbagi pengalaman antar guru, mengenai kesulitan pada saat praktik menggambar seni finger painting. Tujuan yang dapat diperoleh dari kegiatan finger painting yaitu akan tercipta interaksi timbal balik langsung antara peserta didik dan guru.

a. Alat dan bahan finger painting diantaranya tepung sagu, pewarna kue yang berwarna tajam, sabun cair dan minyak sayur.

b. Proses Pembuatan

Larutkan tepung sagu dengan air, kemudian masukkan 1 sendok teh sabun cair, serta minyak sayur dan pewarna secukupnya. Aduk didalam panci hingga merata lalu masak diatas kompor sambil terus diaduk-aduk. Usahakan tepung sagu jangan terlalu masak karena hasilnya akan kurang bagus. Proses pembuatan cat dapat pula dilakukan dilakukan dengan menggunakan serpihan sabun yaitu: kocok serpihan sabun hingga menyerupai adonan busa kue. Tambahkan sedikit catsebagai pewarna (cat yang digunakan bebas asalkan tidak berbahaya untuk anak). Salah satu contoh cat yang dapat digunakan yaitu cat air, menggunakan pewarna makanan ataupun pewarna dari bahan alam. Cat untuk kegiatan finger painting harus aman bagi anak karena cat tersebut akan langsung bersentuhan dengan jari-jari anak. Oleh karena itu guru harus teliti dan selektif jika memilih cat. Peralatan finger painting peralatan yang digunakan adalah kertas manila atau kertas khusus untuk menggambar dengan tangan, kain lap dan mangkuk-mangkuk kecil sebagai tempat cat. 
Langkah langkah pelatihan finger painting ini adalah :

a. Pelatihan tahap pertama

1) Panitia melakukan presentasi presentasi untuk mengenalkan berbagai media melukis, model pembelajaran, dan cara untuk menjadi guru yang kreatif.

2) Guru diberikan waktu untuk menunjukkan bakat atau potensi yang dimiliki. Pengalaman praktik seni rupa yang sudah pernah dilakukan sebelumnya.

b. Pelatihan tahap kedua

1) Panitia menjelaskan tentang materi seni rupa, berbagai macam media dan teknik dalam melukis, salah satunya finger painting.

2) Panitia mempersiapkan alat dan bahan untuk pelatihan

3) Panitia mengkondisikan posisi guru yang akan melaksanakan praktik

4) Proses pelaksanaan membuat bahan finger painting yaitu tepung kanji dan tepung terigu diaduk rata, masukkan air diaduk rata sehingga adonan menjadi encer, selanjutnya adonan dimasak hingga mendidih sambil diaduk terus hingga mengental seperti lem. Setelah itu, angkat dan dinginkan.

5) Tahap selanjutnya panitia dan guru menyiapkan kertas gambar besar.

c. Pelatihan tahap ketiga

Proses pelatihan dengan mempraktikkan langsung finger panting dengan alat dan bahan yang sudah dipersiapkan.

d. Pelatihan tahap keempat

Panitia memaparkan manfaat pelatihan finger painting bagi guru dan bagi siswa. Manfaat bagi guru diantaranya :

1) Guru dapat lebih kreatif dalam memberikan materi dan praktik seni lukis khususnya teknik finger painting.

2) Finger painting mempunyai kandungan spiritual, melatih konsentrasi.

3) Melalui pelatihan ini guru bisa meningkatkan pembelajaran yang lebih aktif, menciptakan ide-ide untuk menunjang kreativitas seorang anak.

Sedangkan manfaat bagi anak diantaranya :

1) Melatih motorik halus anak. Dengan menggunakan tangannya untuk melukis akan membantu melenturkan jari-jari anak. 
2) Mengembangkan koordinasi mata dan tangan. Mengembangkan indra peraba/ sensori. Anak bisa merasakan dan membedakan tekstur yang berbeda.

3) Mengembangkan kemampuan berbahasa. Anak akan belajar kosa kata baru dalam permainan ini. misalnya, lengket, nama warna, konsep dasar dan halus, anak tidak akan tahu kasar atau halus jika ia tidak pernah bersentuhan.

4) Membantu anak untuk fokus atau berkonsentrasi. Fokus dan konsentrasi membantu anak dimasa depan. Salah satu contohnya bertahan dalam belajar, bertahan menyelesaikan persoalan. Proses praktik finger painting ini dapat membuat anak menjadi sibuk atau memiliki kesibukan dalam berkarya sehingga ia bisa bertahan untuk fokus satu hal.

5) Mengenalkan warna. Finger painting bisa menjadi alternatif orang tua atau pendidik untuk mengenalkan warna pada anak usia dini. Selain pengenalan warna, dengan teknik finger print maka anak akan belajar memadukan gradasi warna. Praktik finger painting dapat mengajarkan anak untuk mengeksplorasi berbagai.

6) Timbulnya semangat keceriaan. Anak akan merasa senang ketika mencampur warna-warna, akan lebih senang ketika menemukan hal-hal baru yaituketika mencampur atau memadukan warna menjadi berubah dan terlihat lebih indah.

7) Mengembangkan imajinasi dan kreativitas. Melukis dengan media apapun akan mengembangkan imajinasi dan kreativitas anak. Anak akan bebas menorehkan apapun pada kertasnya. Anak harus diberikan kebebasan, agar timbulnyarasaingin mencoba hal baru. Mengeksplorasikan hal baru diantaranya mengeksplorasi media dan objek gambar sehingga imajinasinya keluar secara spontan.

8) Keberanian. Saat anak menyentuh tekstur yang terlihat lengket mungkin ada beberapa anak yang takut dan merasatidak ingin menyentuh. Disinilah peranan guru, guru hendaknya memotivasi anak, atau memberikan contoh sehingga anak akan merasa berani mencoba meletakkan tanganya pada tekstur warna. Hal tersebut sebagai awal untuk melatih keberanian anak.

9) Menumbuhkan rasa percaya diri. Finger painting merupakan salah satu teknik dalam karya seni lukis. Anak akan merasa 
leluasa dalam berkarya. Anak akan merasa senang jika ia menorehkan karya sendiri. Terlebih dari itu, Anak akan merasa bangga dan senang apabila karya anak tersebut diberikan apresiasi berupa pujian ataupun penghargaan. Apresiasi tersebut akan membuat anak timbul rasa percaya diri. Timbulnya rasa percaya diri ini tentunya akan berguna bagi anak dalam mencoba aktivitas seni yang lain. Misalnya menggambar dan melukis yang lebih kompleks.

10) Sebagai media emosi bagi anak. Anak akan menuangkan emosi jiwanya dengan warna-warna yang sesuai dengan keinginan dan kondisi emosionalnya.

11) Melatih kesabaran anak. Melukis dengan teknik finger print tidak memerlukan waktu yang lama, tetapi tetap memerlukan kesabaran. Dimana anak dilatih untuk mempersiapkan warna, anak mencoba mencampur warna sesuka hati yang mesti memerlukan waktu dan proses. Maka disinilah anak dilatih kesabaran karena untuk mencapai suatu keinginan memerlukan semangat., kesabaran, waktu serta tenaga.

e. Pelatihan tahap kelima.

Tahapan kelima merupakan tahapan akhir dimana penyelenggara/ panitia memaparkan kekurangan dan kelebihan diadakannya pelatihan serta penutup. Setiap kegiatan yang dilakukan dalam proses pembelajaran pasti memilikikekurangan dan kelebihan. Begitu pula dengan kegiatan pelatihan finger painting ini. Kelebihan pelatihan finger painting yaitu untuk memberikan pelatihan guru agardapat meningkatkan kreativitas dalam menunjang peserta didik yang lebih kreatif. kegiatan pelatihan ini dapat mengembangkan bakat dan kemampuan seni yang dimiliki oleh guru. Pelatihan ini tidak menggunakan banyak biaya karena hanya menggunakan beberapa media saja yang dapat disiasati dengan bahan pewarna alami. Kekurangan pelatihan finger painting adalah guru harus selalu memantau anak pada tahap awal hingga akhir. Harus dilakukan evaluasi terhadap pelatihan ini karena kemampuan yang sudah dimiliki, sudah faham konsep dasarnya, jika tidak dilakukan/ dipraktikan secara berkelanjutan/ diulang-ulang, maka pelatihannya menjadi percuma untuk diterapkan (Astrea, 2015). 


\section{PEMBAHASAN}

Finger painting merupakan media untuk membantu mengkespresikan seni dan memberikan peluang bagi anak untuk meluangkan ide-ide imajinasinya. Finger painting bukan hanya dilihat dari karya yang dihasilkan, melainkan proses ketika anak membuat karya. Melalui pelatihan ini guru bisa meningkatkan potensi yang dimiliki terutama pada bidang melukis. Masa anak usia dini biasanya disebut dengan golden age atau masa emas, dimana seluruh potensi anak mengalami masa peka untuk tumbuh dan berkembang secara tepat dan hebat. Mereka belum mampu mengembangkan potensi yang ada, Maka dari itu dibutuhkan upaya dari seorang pendidik untuk mencapai optimalisasikan semua aspek potensi anak. Guru kreatif harus mampu mendorong anak, sehingga anak akan memahami potensi yang ada pada dirinya, agar memiliki kemajuan yang pesat. Pendidik sebagai sosok yang berperan dalam perkembangan anak, menyiapkan dan melaksanakan pembelajaran yang dapat meningkatkan kreativitas anak.Pelatihan finger painting tidak ada aturan yang baku, yang diutamakan dalam pelatihan finger painting adalah bagaimana memotivasi anak agar mereka mau melakukan kegiatan tanpa ragu dan penuh percaya diri. Anak harus merasa senang, merasa semangat dan penuh kepercayaan diridalam melaksanakan praktik finger painting,memadukan warna diatas bidangdengan menggunakan jari-jari mereka. Setiap anak memiliki karakter dan sifat yang berbeda, dimana guru yang sudah terlatih dalam metode dan teknik pembelajaran, harus tetap dapat memotivasi siswa yang tidk aktif.

Guru harus menggunakan media, teknik serta kegiatan yang beragam. Motivasi siswa dapat ditumbuhkan dengan melakukan halhal yang baru, agar anak tidak bosan. Menggunakan media, teknik serta kegiatan yang beragam akan membantu anak semakin bersemangat dan ingin mencoba. Melakukan hal yang samasecara terus menerus bisa menimbulkan kebosanan dan menurunkan motivasi belajar siswa. Siswa yang bosan cenderung mengganggu proses belajar. Variasi belajar akan membuat siswa tetap berkonsentrasi dan termotivasi. Sesekali mencoba sesuatu yang berbeda dengan menggunakan metode belajar yang bervariasi. Jadikan siswa berperan aktif pada kegiatan ini. Akan lebih baik jika proses pembelajaran yang dilakukan kepada siswa mencakup banyak kreatifitas, berpetualang hingga menyelesaikan 
masalah dan membuat sesuatu yang baru sebagai pengalaan untuk siswa. Guru harus membiarkan siswa berkreasi sendiri sesuka hati, membuat tugas yang menantang namun realitis dan sesuai. Buatlah proses belajar siswa sesuai dengan minat mereka,menarik perhatian siswa. Guru harus memberitahukan tujuan dari pembelajaran kepada siswa agar siswa merasa lebih percaya diri. Guru harus menciptakan suasana kelas yang kondusif. Suasana yang kondusif harus selalu dijaga, agar tercipta rasa nyaman kepada guru dan siswa. Simpanlah peralatan seni rupa sesuai dengan jenis-jenisnya agar ketika diambil tidak membingungkan. Apabila peserta didik belajar disuatu kelas yang menghargai dan menghormati mereka, tidak memandang kemampuan akademis dan latar belakang mereka maka mereka cenderung terdorong untuk terus mengikuti proses belajar siswa. Guru juga harus memiliki komunikasi yang baik. Ciptakan komunikasi yang baik kepada peserta didik, khususnya anak usia dini. Komunikasi yang positif berpengaruh besar terhadap kepercayaan diri, harga diri, kemandirian, dan keberanian anak-anak. Mereka akan selalu mendapatkan dukungan untuk mempelajari apa saja, tidak minder, tidak takut salah, karena apabila mereka melakukan kesalahan yang ada hanyalah motivasi yang kita berikan agar mereka lebih berani lagi, mencoba lagi, dan belajar lagi.

Guru harus menciptakan pembelajaran yang menyenangkan, yang disertai dengan permainan yang menyenangkan yang dipadukan dengan materi pembelajaran. Siswa akan lebih menyukai pembelajaran yang bersifat melakukan permainan yang menyenangkan sehingga anak-anak akan lebih semangat dan antusias. Guru juga harus menciptakan suasana yang colourfull. Guru harus mengatur kelas dengan penuh warna-warna yang menarik, menumbuhkan semangat, warna yang ceria. Mereka akan menyukai ruangan sehingga proses belajar mengajar lebih menyenangkan. Apabila mereka sudah nyaman, mereka akan lebih fokus dan point pentingnya adalah mereka akan melakukan pembelajaran secara aktif. Sediakanlah banyak media bermain yang menunjang pembelajaran. Ada perpaduan antara kepribadian, minat belajar, gaya belajar, proses berpikir serta perkembangan anak. Motivasi anak harus terus berkembang, harus dapat mendukung dan memperhatikan pentingnya kepercayaan, minat, gaya belajar,proses berpikir dan perkembangan anak itu sendiri.Sejalan dengan bertambah usia anak, maka minat mulai ikut mengambil peran dalam membangun motivasi. Minat anak dapat 
diobservasi dari ketertarikan anak melakukan sesuatu, intensitas dan frekuensi ia menghabiskan waktu untuk melakuksn sesuatu hal. Ketika menghargai memperhatikan anak-anak mereka tertarik pada hal tertentu, berikan dukungan dan tantangan agar dapat meningkatkan bakat yang anak miliki. Perkuat rasa percaya diri anak. Dengan memberikan motivasi, namun terus pupuk minat anak kearag yang benar dengan memberi keteladanan(Juliani, 2011).

Guru mempunyai tugas dan tanggung jawab untuk melihat segala sesuatu yang ada pada diri anak termasuk potensi yang dimiliki peserta didik. Melalui guru diharapkan mampu menghasilkan peserta didik yang bukan hanya cerdas secara intelektual, melainkan cerdas secara emosional dan spiritual dan mempunyai kecakapan hidup atau life skil. Hal tersebut akan terwujud apabila guru mempunyai komitmen yang kuat dalam meningkatkan potensi mereka. Pelatihan keterampilan kreativitas ini merupakan keterampilan yang didesain untuk meningkatkan kreativitas yang lebih kreatif khususnya pada seni finger painting ini. Untuk meningkatkan semangat peserta didik, guru memang harus dituntut untuk memiliki kreativitas berdasarkan kemampuan yang dimiliki nya. Kreativitas muncul sebagai wujud dari berfikir menuju kearah yang unggul dan berkwalitas.Guru yang kreatif harus mampu mengatur kecakapan diri peserta didik, waktu belajar, menyelesaikan masalah, membangun harga diri, meningkatkan keterampilan, merencanakan kegiatan-kegiatan positif, menjadikan anak sebagai penjelajah, dan bisa memanfaatkan sumberdaya yang berada dimasyarakat. Menjadi guru kreatif tidak terbentuk secara cepat dan spontan, tetapi harus melewati berbagai tantangan sehingga guru dan murid akan lebih baik di masa depan.

Ketika guru telah mempunyai kreativitas pada metode pembelajarannya maka anak akan memperoleh beberapa aspek kreativitas yaitu kelancaran dimana anak bisa mengemukakan ide-ide yang ada dipikirannya dengan lancar dan mampu mencetuskan banyak gagasan dalam permasalahan. Anak juga akan memiliki kelenturan tubuh sehingga anak akan mempunyai kemampuan untuk mengemukakan berbagai alternatif dalam pemecahan masalah sesuai ide yang dimikinya. Anak juga akan memiliki keaslian yang mana berarti bahwa anak akan menghasilkan suatu karya yang sesuai dengan hasil fikirannya sendiri dan anak akan memiliki sifat elaborasi sehingga anak memiliki kemampuan untuk memperluas ide-ide yang ada dalam pikiran anak atau memperkaya ide-ide yang ada dalam 
pikiran anak-anak(Abdullah, 2016). Guru harus memiliki pengalaman dalam pelatihan untuk meningkatkan profesionalisme, dengan memanfaatkan waktu untuk menambah pengetahuan dan keterampilan. Pengalaman dalam mengikuti pelatihan, baik pelatihan yang diadakan disekolah maupun luar sekolah pasti memberikan pengalaman yang berarti serta memberikan pengaruh yang besar terhadap wawasan menuju guru professional(Mulyawan, B, 2013).

\section{KESIMPULAN}

Guru harus mempunyai kreativitas agar dapat melahirkan peserta didik yang potensial karena guru mempunyai tugas untuk memegang peranan yang strategis salah satunya yaitu membentuk dan menumbahkan bakat atau potensi yang ada pada diri anak. Keberhasilan menyelenggarakan pendidikan dapat dilihat sejauh mana proses pembelajaran yang dilakukan oleh seorang guru, karena untuk mencapai proses pembelajaran itu berhasil atau tidaknya ditentukan oleh guru yang dapat menjalankan proses belajar mengajar secara kreatif, inovatif dan potensial. Tujuan peningkatan kemampuam kreativitas guru selain untuk menunjang mutu pendidikan tujuannya adalah agar guru bisa menghadapi tantangan pada kondisi apapun, karena pada era ini merupakan era globalisasi yang penuh dengan persaingan. Salah satu cara untuk meningkatkan kreativitas seorang guru adalah dengan memberikan pelatihan secara berkala.Pelatihan yang dilaksanakan dalam penelitian ini yaitu finger painting khususnya untuk guru anak usia dini. Pelatihan finger painting ini sebagai proses pengembangan kreativitas guru dalam menyampaikan materi maupun praktik pembelajaran. Pendidik sebagai sosok yang berperan dalam perkembangan anak, harus dapat menyiapkan dan melaksanakan pembelajaran dengan tepat agar meningkatkan kreativitas anak. Pelatihan finger painting yang diutamakan adalah bagaimana memotivasi anak agar mereka mau melakukan kegiatan tanpa ragu dan penuh percaya diri untuk memainkan warna diatas media menggunakan jari-jari mereka sesuai dengan imajinasi masing-masing peserta didik. Hasil dari pelatihan ini memiliki banyak kelebihan atau manfaat yang didapatkan oleh guru PAUD, sehingga dapat diterapkan dalam proses pembelajaran secara tepat. 


\section{DAFTAR PUSTAKA}

Abdullah, Ramli. 2016, Pembelajaran dalam Prespektif Kreativitas Guru dalam Pemanfaatan Media Pembelajaran, lantannida Journal. 4 (1).

Adirestury, Fitranty. 2017, Pengaruh Self-Effycacy Guru dan Kreativitas Guru Terhadap Motivasi Belajar Siswa dan Implikasinya Terhadap Prestasi Belajar Pada Masa Pelajaran Ekonomi, Jurnal Wahana Pendidikan 4 (1).

Andriana, J. (2018). Kinerja Guru PAUD ditinjau dari Kualifikasi Pendidik, Pengalaman Mengajar, dan Pelatihan. Jurnal Ilmiah Potensia, 3(2), 83-88.

Anggraini, S., Jaya, T. B., \& Sofia, A. (2018). Pengaruh Aktivitas Permainan Finger Painting terhadap Pengenalan Warna Anak Usia 5-6 Tahun. Jurnal Pendidikan Anak, 4(2).

Astrea, Nina. 2015, Penerapan Metode Bermain Melalui Kegiatan Finger Painting untuk Meningkatkan Kemampuan Motorik Halus, e-Jurnal PG PAUD Universitas Pendidikan Ganesha Jurusan Pendidikan Guru Pendidikan Anak Usia Dini, 3 (1).

Fitriani Dewi, Aisyah dkk, Aplikasi Kegiatan Main Finger Painting dalam Peningkatan Kreativitas Motorik Halus Anak Usia Dini, 6 (2). 1-14.

Ismiyanto. 2018, Pelatihan Mengajar Seni Rupa Berbasis Konservasi Lingkungan bagi para Guru Sekolah Dasar, Rekaya 16 (1). Jufni, Muhammad. 2015, Kreativitas Guru PAI dalam Pengembangan Bahan Ajar di Madrasah Aliyah Jeumala Amal Lueng Putu, Jurnal Magister Administrasi Pendidikan, Vol, 3, No 4.

Marlina, L., \& Mayar, F. (2020). Pelaksanaan Kegiatan Finger Painting dalam Mengembangkan Kreativitas Seni Anak di Taman Kanak-Kanak. Jurnal Pendidikan Tambusai, 4(2), 10181025.

Mulyawan, B. (2013). Pengaruh Pengalaman dalam Pelatihan terhadap Peningkatan Kompetensi Profesional Guru. Media Komunikasi FPIPS, 11(1).

Nurjanah, N. (2017). Pengaruh Kegiatan Finger Painting Terhadap Perkembangan Motorik Halus Anak Usia Pra Sekolah di Tk At-Taqwa Cimahi. Jurnal Keperawatan BSI, 5(2). 
Pratiwi, P. Y., \& Budisetyani, I. W. (2013). Emosi dan Penggunaan Warna Dominan pada Kegiata Mewarnai Anak Usia Dini. Jurnal Psikologi Udayana Vol, 1, 160-170.

Rahmawati, W., \& Pratisti, W. D. (2018). Efektifitas Pembelajaran Fikome (Finger Painting, Kolase Dan Menganyam) Untuk Meningkatkan Kemampuan Motorik Halus Anak (Doctoral dissertation, Universitas Muhammadiyah Surakarta).

Rahmi, Putri, Mengembangkan Kecerdasan social dan Emosional Anak Usia Dini. Jurnal BUNAYYA: Jurnal Pendidikan Anak. 6 (2), 126.

Saepudin, E., \& Damayani, N. A. (2016). Literasi Media Bagi Guru Paud Di Kecamatan Cicalengka. Dharmakarya, 5(1).

Sandi, N. V., \& Setyorini, R. (2018). ANALISIS KEGIATAN BIMBINGAN BELAJAR PADA ANAK USIA DINI DALAM KREATIVITAS PEMBELAJARAN FINGER PAINTING (Melukis Terhadap Peningkatan Motorik Halus). Generasi Emas: Jurnal Pendidikan Islam Anak Usia Dini, 1(2), 128-143.

Sri Judiani, Kreativitas dan Kompetensi Guru Sekolah Dasar, Jurnal Pendidikan dan Kebudayaan, 17 (1).

Suciati, D. A. K. G., Suarni, N. K., Ujianti, P. R., \& Psi, S. (2016). Pengaruh Kegiatan Finger Painting Berbasis Teori Lokomosi Terhadap Keterampilan Motorik Halus Anak. Jurnal Pendidikan Anak Usia Dini Undiksha, 4(2).

Sundari, R., Karyono, T., \& Soeteja, Z. (2020). Pengembangan Buku Pengayaan Bermuatan Lokal Bagi Mahasiswa PGSD. Muallimuna: Jurnal Madrasah Ibtidaiyah, 6(1), 31-43.

Vitamami, L (2013). Peningkatan Kemampuan Motorik Halus dengan Finger Painting pada Kelompok A2 RA Babussalam Krian Sidoarjo. Jurnal Mahasiswa. 